\title{
IDENTIFIKASI KESULITAN BELAJAR SISWA PADA OPERASI HITUNG BILANGAN DALAM MENYELESAIKAN SOAL CERITA SMPN 2 TANJUNG PALAS
}

\author{
Ardiansyah $^{1}$, Hariaty Hamid ${ }^{2}$, Alfian Mucti $^{3}$ \\ ${ }^{1}$ Mahasiswa Strata 1 Pendidikan Matematika, Universitas Borneo Tarakan \\ ${ }^{2,3}$ Jurusan Pendidikan Matematika, Universitas Borneo Tarakan \\ 1ardi.1000duren@gmail.com \\ 2hariaty.pmat@gmail.com \\ 3alfianmucti@borneo.ac.id
}

\begin{abstract}
This study aims to find out how much percentage of each student's learning difficulties at number operations in solving the story problems in class VIII of Tanjung Palas State Middle School 2. This research was conducted in the odd semester of 2018/2019. This type of research is quantitative. The sampling technique used by Nonprobability Sampling with the type of Purposive Sampling sampling technique is the determination of samples with certain considerations, where the number of students sampled is 26 students. The results showed that the student learning difficulties with the highest percentage average score for students of Tanjung Palas 2 Public Middle School were operating indicators of $38.72 \%$ with a high category, followed by a principle of $43.59 \%$, with a high category of concepts with categories $48.46 \%$ high, and $62.05 \%$ facts with a low category.
\end{abstract}

Keywords: Student Learning Difficulties, Count Numbers Operations.

\begin{abstract}
Abstrak
Penelitian ini bertujuan mengetahui seberapa besar persentase dari masing-masing kesulitan belajar siswa pada operasi bilangan dalam menyelesaikan soal cerita dikelas VIII SMP Negeri 2 Tanjung Palas. Penelitian ini dilaksanakan pada semester ganjil tahun 2018/2019. Jenis penelitian ini adalah kuantitatif. Teknik pengambilan sampel yang digunakan Nonprobability Sampling dengan jenis teknik sampling Purposive Sampling yaitu penentuan sampel dengan pertimbangan tertentu, dimana jumlah siswa yang dijadikan sampel adalah 26 siswa. Hasil penelitian menunjukkan bahwa kesulitan belajar siswa yang paling besar persentasenya rata-rata skornya untuk siswa SMP Negeri 2 Tanjung Palas adalah pada indikator operasi sebesar 38,72\% dengan kategori tinggi, diikuti prinsip sebesar 43,59\%, dengan kategori tinggi konsep sebesar dengan kategori tinggi 48,46\%, dan fakta sebesar $62,05 \%$ dengan kategori rendah.
\end{abstract}

Kata kunci: Kesulitan Belajar Siswa, Operasi Hitung Bilangan.

Matematika tidak hanya cukup operasi tambah, kurang, kali, dan bagi. Jamaris (2014: 177), "menyatakan matematika adalah suatu pelajaran yang penting dipelajari karena matematika merupakan pemahaman terhadap pola perubahan yang terjadi didalam dunia nyata dan pikiran manusia".

Matematika juga merupakan salah satu bidang studi yang ada pada semua jenjang pendidikan, mulai dari tingkat sekolah dasar hingga perguruan tinggi. Bahkan matematika diajarkan ditaman kanak-kanak secara informal. Belajar matematika merupakan suatu syarat cukup untuk melanjutkan pendidikan kejenjang berikutnya. Ada banyak alasan perlunya belajar matematika, sesuai dengan penjelasan dalam tujuan pembelajaran matematematika

Tetapi, didalam pencapaian tujuan pembelajaran matematika tidak selamanya berjalan dengan lancar dan baik, terkadang dalam proses pembelajaran tersebut bisa saja mengalami hambatan. Berdasarkan hasil obeservasi yang dilakukan oleh peneliti melalui pengamatan di dalam kelas 
khususnya dikelas VIII pada materi operasi bilangan terlihat bahwa guru dalam kegiatan belajar mengajar banyak memberikan pancingan untuk mengetahui sejauh mana pemahaman siswa pada materi tersebut. Namun hanya beberapa siswa yang menjawab dengan benar, lalu pada saat guru memberikan contoh soal dipapan tulis siswa lambat dalam menyelesaikan soal tersebut, siswa membutuhkan bimbingan dari guru untuk menyelesaikan soal, dengan kata lain siswa tidak dapat menyelesaikan soal dengan hasil kemampuannya sendiri. Dari masalah tersebut teridentifikasi bahwa siswa kesulitan dalam belajar matematika.

Indikasi bahwa siswa mengalami kesulitan belajar tersebut diperkuat juga dengan hasil wawancara yang dilakukan oleh peneliti dengan salah satu guru matematika yang baru saja selesai mengajarkan materi bilangan diperoleh informasi bahwa : (1) ada beberapa siswa masih belum bisa mengurutkan bilangan bulat, (2) siswa belum lancar dalam melakukan operasi hitung (penjumlahan, pengurangan, pembagaian, dan perkalian), (3) ada beberapa siswa kesulitan memahami soal cerita operasi hitung bilangan. Selain itu, siswa mengalami kesulitan belajar diperkuat dengan siswa memperoleh hasil belajar yang rendah, dari nilai ujian semester siswa kelas VIII SMP Negeri 2 Tanjung Palas hanya memperoleh nilai rata-rata sebesar 31,8 dari nilai KKM yang diharapkan yaitu 60. Hal ini mengindikasikan bahwa siswa mengalami kesulitan belajar di kelas.

Berdasarkan latar belakang masalah di atas, maka peneliti tertarik untuk melakukan suatu penelitian yang berjudul "Identifikasi Kesulitan Belajar Siswa Pada Operasi Hitung Bilangan Dalam Menyelesaikan Soal Cerita di Kelas VIII SMP Negeri 2 Tanjung Palas."

Tujuan penelitian ini, yaitu untuk mengetahui seberapa besar persentase dari masing-masing kesulitan belajar siswa pada operasi bilangan dalam menyelesaikan soal cerita dikelas VIII SMP Negeri 2 Tanjung Palas.

Dalam aktivitas belajar bagi setiap siswa, tidak selamanya berjalan dengan lancar. Terkadang dengan mudah memahami apa yang telah dipelajari dan terkadang sulit. Kesulitan belajar merupakan hal yang tidak asing bagi dunia pendidikan. Kesulitan belajar bisa dialami dari jenjang pendidikan sekolah dasar sampai dengan perguruan tinggi. Kesulitan belajar menurut dugaan banyak orang dialami oleh siswa yang berkemampuan rendah saja. Menurut Khadijah dalam Wahab (2016: 192), "menyatakan kesulitan belajar ternyata bukan hanya dialami siswa berkemampuan rendah, tetapi bisa dialami oleh siswa yang berkemampuan sedang maupun siswa yang berkemampuan tinggi”. Sebelum membahas tentang kesulitan belajar matematika terlebih dahulu kita mengetahui apa itu kesulitan belajar. Hammil dalam Subini (2016: 14), "Kesulitan belajar adalah gangguan atau hambatan yang dialami seseorang baik mendengarkan, bercakap-cakap, membaca, menulis, menalar, dan/atau dalam berhitung". Menurut Hati (2015: 5), kesulitan belajar siswa dalam menguasai matematika yaitu: "kesulitan belajar fakta, konsep, prinsip, dan operasi". 


\section{METODE}

Penelitian ini akan dilaksanakan pada hari kamis tanggal 9 dan wawancara dilakukan pada hari jumat 10 agustus 2018 semester ganjil tahun ajaran 2018/2019. Lokasi penelitian ini di kelas VIII SMP Negeri 2 Tanjung Palas yang beralamat Jl. AMD RT 003 Bira Desa Antutan Kabupaten Bulungan provinsi Kalimantan Utara. Dalam penelitian ini, sampel diambil dengan menggunakan teknik nonprobability sampling dengan teknik purposive sampling. Sugiyono (2015: 124) "mengutarakan bahwa purposive sampling adalah teknik penentuan sampel dengan mempertimbangkan hal-hal tertentu". Sampel yang diambil dalam penelitian ini berdasarkan nilai terendah yang diambil dari hasil ujian semester, dari dua kelas peneliti mengambil satu kelas yaitu kelas VIII A dengan jumlah siswa 26 orang yang memperoleh nilai terendah yang peneliti gunakan sebagai sampel penelitian. Untuk jumlah siswa Kelas VIII SMP Negeri 2 Tanjung Palas dapat dilihat pada tabel 3.1 dibawah ini.

Tabel 1. Jumlah Siswa Kelas VIII

\begin{tabular}{cc}
\hline Kelas & Jumlah Siswa \\
\hline VIII A & 26 \\
\hline VIII B & 26 \\
\hline Total & 52 \\
\hline (Sumber: Sekolah SMP Negeri 2 Tanjung Palas)
\end{tabular}

Instrumen yang digunakan dalam penelitian ini adalah tes uraian. Setelah siswa mengerjakan instrumen yang diberikan, peneliti melakukan wawancara. Wawancara yang dilakukan dalam penelitian ini adalah wawancara tidak terstruktur dan diberikan kepada beberapa siswa untuk mengklarifikasikan jawaban siswa pada soal tes. Wawancara ini dilakukan setelah siswa mengerjakan soal tes yang diberikan. Dalam wawancara peneliti akan terus menggali informasi sehingga akan didapatkan data yang sebenarnya. Data yang akan dianalisis berdasarkan data yang diperoleh dari hasil tes dan disesuaikan dengan hasil wawancara.

Analisis data dalam penelitian ini menggunakan statistik deskriptif kuantitatif untuk menjawab rumusan masalah yang disusun. Statistik deskriptif kuantitatif digunakan menganalisis data dengan cara mendeskripsikan atau menggambarkan data yang telah terkumpul yakni berupa hasil tes. Analisis data yang akan dilakukan yaitu:

1. Menghitung nilai siswa berdasarkan rubrik penskoran menggunakan rumus berikut:

$$
\text { Nilai }=\frac{\text { Skor Perolehan }}{\text { Skor Maksimal }} \times 100
$$

2. Peneliti melakukan perhitungan rata-rata persentase kesulitan belajar dari keseluruhan siswa dengan menggunakan rumus berikut:

$$
\tilde{x}=\frac{\sum x_{i}}{n}
$$

\section{Keterangan:}

$\tilde{x} \quad=$ Mean (Rata-rata) 


$$
\begin{array}{ll}
\sum x_{i} & =\text { Jumlah tiap data } \\
n & =\text { Banyaknya data }
\end{array}
$$

3. Kemudian untuk menghitung persentase pencapain pada setiap indikator dapat dihitung menggunakan rumus berikut:

Persentase Per Indikator $=\left|\left(\frac{\text { Rata }- \text { rata Per Indikator }}{\text { Skor Maksimal Per Indikator }}\right) \times 100 \%\right|$

4. Dari hasil analisis persentase tersebut baru kemudian dikualifikasikan dalam tabel berikut.

Tabel 2. Kategori Tingkat Kesulitan Belajar Siswa

\begin{tabular}{cc}
\hline Persentase Tingkat Kesulitan Belajar (\%) & Kategori \\
\hline $\mathrm{P}>75$ & Sangat Rendah \\
\hline $50<\mathrm{P} \leq 75$ & Rendah \\
\hline $25<\mathrm{P} \leq 50$ & Tinggi \\
\hline $\mathrm{P} \leq 25$ & Sangat Tinggi \\
\hline
\end{tabular}

(Sumber : Arikunto, 2011 (Modifikasi Ishak))

\section{HASIL DAN PEMBAHASAN}

Penelitian ini dilaksanakan di SMP Negeri 2 Tanjung Palas pada semester ganjil pada tahun ajaran 2018/2019, dilakukan selama 3 hari pada tanggal 6 agustus 2018, 9 agustus 2018, dan 10 agustus 2018.

Wawancara dilakukan terhadap siswa yang memperoleh nilai terendah, wawancara dilakukan setelah peneliti memberikan instrumen tes, setelah siswa menyelesaikan instrumen tes maka peneliti mengolah data terlebih dahulu, kemudian baru melakukan wawancara terhadap siswa yang terpilih. Tujuan dilakukannya wawancara adalah untuk menggali informasi mengenai hasil pekerjaan siswa agar mendukung dan memperkuat hasil data penelitian kesalahan siswa. Pada penelitian ini peneliti tidak memberikan perlakuan pada sampel. Setelah instrumen diberikan kepada siswa dan peneliti memperoleh kembali hasil lembar kerja siswa, maka peneliti mengoreksi hasil pekerjaan siswa dengan memberikan skor pada setiap butir soal. Berdasarkan penelitian pengumpulan data dari yang telah dilakukan di SMP Negeri 2 Tanjung Palas pada mata pelajaran Matematika pada materi Operasi Hitung Bilangan diperoleh hasil sebagai berikut.

\section{Hasil Analisis Deskriptif Keseluruhan Sampel}

Tabel 3. Kesulitan Belajar Siswa Menyelesaikan Soal Cerita

\begin{tabular}{cccc}
\hline Rentang Skor & Kategori & Jumlah siswa & Persentase Jumlah Siswa (\%) \\
\hline $\mathrm{P}>75$ & Sangat Rendah & 6 & 23,07 \\
\hline $50<\mathrm{P} \leq 75$ & Rendah & 4 & 15,4 \\
\hline $25<\mathrm{P} \leq 50$ & Tinggi & 14 & 53,84 \\
\hline $\mathrm{P} \leq 25$ & Sangat Tinggi & 2 & 7,69 \\
\hline & Total & 26 & 100 \\
\hline
\end{tabular}

Tabel 3 menunjukkan seberapa besar persentase kesulitan belajar siswa pada operasi hitung bilangan dalam menyelesaikan soal cerita. Pada kategori tingkat kesulitan sangat tinggi terdapat 2 siswa dengan persentase $7,69 \%$, pada kategori tinggi terdapat 14 siswa dengan persentase sebesar 
$53,85 \%$, pada kategori rendah terdapat 4 siswa dengan persentase sebesar $15,4 \%$, pada kategori sangat rendah terdapat 6 siswa dengan persentase 23,07\%.

Kemudian peneliti menguraikan data tersebut untuk melihat kesulitan belajar siswa setiap indikator. Adapun pengelompokkan hasil kesulitan belajar siswa berdasarkan indikator dapat dilihat pada tabel 4.3 sebagai berikut.

Tabel 4. Rata-rata Skor Perindikator

\begin{tabular}{ccc}
\hline Indikator Kesulitan Belajar & Skor & Kategori \\
\hline Fakta & 62,05 & Rendah \\
\hline Konsep & 48,46 & Tinggi \\
\hline Prinsip & 43,59 & Tinggi \\
\hline Operasi & 38,72 & Tinggi \\
\hline
\end{tabular}

Berdasarkan tabel 4 tersebut, kesulitan belajar siswa di SMP Negeri 2 Tanjung Palas di kelas VIII untuk indikator fakta dengan skor rata-rata 62,05 termasuk dalam kategori rendah, artinya siswa tidak begitu mengalami kesulitan belajar pada indikator fakta. Pada indikator konsep dengan skor rata-rata 48,46 termasuk dalam kategori tinggi, artinya siswa mengalami kesulitan belajar pada indikator konsep. Sepertinya halnya siswa tidak mampu mengklafikasikan dan memahami bagianbagian dari operasi bilangan. Pada indikator prinsip dengan skor rata-rata 43,59 termasuk dalam kategori tinggi. Artinya siswa mangalami kesulitan belajar pada indikator prinsip, seperti siswa membuat model matematika yang akan digunakan. Dan pada indikator operasi dengan skor rata-rata 38,72 termasuk dalam kategori tinggi. Artinya siswa mengalami kesulitan belajar pada indikator operasi, seperti siswa tidak menuliskan penyelesaian masalah dari soal operasi hitung bilangan.

\section{Hasil Analisis Deskriptif Berdasarkan Indikator}

Tabel 5. Kategori Kesulitan Belajar Pada Indikator Fakta

\begin{tabular}{cccc}
\hline Rentang Skor & Kategori & Jumlah siswa & Persentase Jumlah Siswa (\%) \\
\hline $\mathrm{P}>75$ & Sangat Rendah & 7 & 26,92 \\
\hline $50<\mathrm{P} \leq 75$ & Rendah & 10 & $38,46 \%$ \\
\hline $25<\mathrm{P} \leq 50$ & Tinggi & 9 & $34,62 \%$ \\
\hline $\mathrm{P} \leq 25$ & Sangat Tinggi & 0 & $0 \%$ \\
\hline & Total & 26 & 100
\end{tabular}

Seperti tabel 5 dapat diketahui bahwa kesulitan belajar siswa pada indikator fakta. Pada kategori tingkat kesulitan sangat tinggi tidak terdapat siswa yang mengalami kesulitan belajar fakta, pada kategori tinggi terdapat 9 siswa dengan persentase sebesar 34,62\%, pada kategori rendah terdapat 10 siswa dengan persentase sebesar $38,46 \%$, pada kategori sangat rendah terdapat 7 siswa dengan persentase $26,92 \%$.

Tabel 6. Kategori Kesulitan Belajar Pada Indikator Konsep

\begin{tabular}{|c|c|c|c|}
\hline Rentang Skor & Kategori & Jumlah siswa & Persentase Jumlah Siswa (\%) \\
\hline $\mathrm{P}>75$ & Sangat Rendah & 1 & 3,85 \\
\hline $50<\mathrm{P} \leq 75$ & Rendah & 11 & 42,3 \\
\hline $25<\mathrm{P} \leq 50$ & Tinggi & 12 & 46,15 \\
\hline $\mathrm{P} \leq 25$ & Sangat Tinggi & 2 & 7,7 \\
\hline \multicolumn{2}{|c|}{ Total } & 26 & 100 \\
\hline
\end{tabular}


Seperti pada tabel 6 dapat diketahui bahwa kesulitan belajar siswa pada indikator konsep. Pada kategori tingkat kesulitan sangat tinggi terdapat 2 siswa dengan persentase sebesar 7,7\%, pada kategori tinggi terdapat 12 siswa dengan persentase sebesar 46,15\%, pada kategori rendah terdapat 11 siswa dengan persentase sebesar $42,3 \%$, pada kategori sangat rendah terdapat 1 siswa dengan persentase $3,85 \%$.

Tabel 7. Kategori Kesulitan Belajar Pada Indikator Prinsip

\begin{tabular}{|c|c|c|c|}
\hline Rentang Skor & Kategori & Jumlah siswa & Persentase Jumlah Siswa (\%) \\
\hline $\mathrm{P}>75$ & Sangat Rendah & 6 & 23,08 \\
\hline $50<\mathrm{P} \leq 75$ & Rendah & 5 & 19,23 \\
\hline $25<\mathrm{P} \leq 50$ & Tinggi & 8 & 30,77 \\
\hline $\mathrm{P} \leq 25$ & Sangat Tinggi & 7 & 26,92 \\
\hline \multicolumn{2}{|c|}{ Total } & 26 & 100 \\
\hline
\end{tabular}

Seperti pada tabel 7 dapat diketahui bahwa kesulitan belajar siswa pada indikator prinsip. Pada kategori tingkat kesulitan sangat tinggi terdapat 7 siswa dengan persentase sebesar $26,92 \%$, pada kategori tinggi terdapat 8 siswa dengan persentase sebesar 30,77\%, pada kategori rendah terdapat 5 siswa dengan persentase sebesar 19,23\%, pada kategori sangat rendah terdapat 6 siswa dengan persentase $19,23 \%$.

Tabel 8. Kesulitan Belajar Siswa Pada Indikator Operasi

\begin{tabular}{cccc}
\hline Rentang Skor & Kategori & Jumlah siswa & Persentase Jumlah Siswa (\%) \\
\hline $\mathrm{P}>75$ & Sangat Rendah & 0 & 0 \\
\hline $50<\mathrm{P} \leq 75$ & Rendah & 7 & 26,92 \\
\hline $25<\mathrm{P} \leq 50$ & Tinggi & 13 & 50 \\
\hline $\mathrm{P} \leq 25$ & Sangat Tinggi & 6 & 23,08 \\
\hline \multicolumn{2}{r}{ Total } & 26 & 100 \\
\hline
\end{tabular}

Seperti pada tabel 8 dapat diketahui bahwa kesulitan belajar pada indikator operasi. Pada kategori tingkat kesulitan sangat tinggi terdapat 6 siswa dengan persentase sebesar 23,08\%, pada kategori tinggi terdapat 13 siswa dengan persentase sebesar 50\%, pada kategori rendah terdapat 7 siswa dengan persentase sebesar $26,92 \%$, pada kategori sangat rendah tidak terdapat siswa yang mengalami kesulitan operasi.

\section{KESIMPULAN}

Berdasarkan tujuan penelitian yaitu untuk mengetahui seberapa besar persentase dari masingmasing kesulitan belajar siswa pada operasi hitung bilangan dalam menyelesaikan soal cerita dikelas VIII SMP Negeri 2 Tanjung Palas, maka dapat disimpulkan persentase rata-rata skor tingkat kesulitan belajar yang dialami siswa pada operasi hitung bilangan dalam menyelesaikan soal cerita secara keseluruhan masih berada pada kategori tinggi yaitu 48,21\%. Selain itu, berdasarkan presentase ratarata skor kesulitan belajar siswa untuk setiap indikator diperoleh sebagai berikut : (1) fakta yaitu sebesar 62,05\% dengan kategori rendah , (2) konsep yaitu sebesar 48,46\% dengan kategori tinggi, (3) prinsip yaitu sebesar 43,59\% dengan kategori tinggi, dan (5) operasi yaitu sebesar 38,72\% dengan kategori tinggi. Dari keempat indikator, kesulitan belajar siswa yang paling besar presentasenya ratarata skornya untuk siswa SMP Negeri 2 Tanjung Palas adalah pada indikator operasi sebesar 38,72\% 
dengan kategori tinggi, diikuti prinsip sebesar 43,59\% dengan kategori tinggi, konsep sebesar 48,46\% dengan kategori tinggi, dan fakta sebesar $62,05 \%$ dengan kategori rendah.

\section{DAFTAR PUSTAKA}

Hati, Sartika. (2015). Analisis Kesulitan Belajar Siswa Pada Operasi Hitung Bilangan Bulat Dalam Menyelesaikan Soal Cerita di Kelas VII SMP Negeri 2 Limboto.

Ishak. 2016. Analisis Kesulitan Siswa Dalam Menyelesaikan Soal Operasi Aljabar Pada Kelas IX SMPIT Ulul Albab. Universitas Borneo Tarakan.

Jamaris, M. (2014). Kesulitan Belajar. Bogor: Ghalia Indonesia.

Sugiyono. (2015). Metode Penelitian Kuantitatif, Kualitatif, dan R\&D. Bandung: Alfabeta.

Subini, Nini. (2016). Mengatasi Kesulitan Belajar Pada Anak. Yogjakarta: Javalitera.

Wahab, Rohmalina. (2016). Psikologi Belajar. Jakarta: Kharisma Putra Utama Offset. 